\title{
Do people remember the temporal proximity of unrelated events?
}

\author{
WiLliam J. Friedman \\ Oberlin College, Oberlin, Ohio \\ AND \\ STEVe M. J. JANSSEN \\ Duke University, Durham, North Carolina \\ and University of Amsterdam, Amsterdam, The Netherlands
}

\begin{abstract}
In the present study, we tested the ability to remember the temporal proximity of two unrelated events that had happened within 7 days of one another. In three experiments, 1,909 participants judged whether pairs of news events, ranging in age from 1 month to about 6 years, had occurred within a week of each other and, if not, how far apart they had occurred. Some event pairs were related, and others were unrelated. For unrelated event pairs, same-week and separation judgments were very poor. Accuracy was much greater for both kinds of judgments when the events were related. Participants often guessed the separation of unrelated event pairs, whereas they frequently deduced the separation or remembered the proximity of related event pairs. For both types of pairs, the participants reported using the strength of the memories or the general period in which the events had occurred.
\end{abstract}

After the passage of months or years, are people able to remember the temporal proximity of unrelated events that occurred at about the same time? If two memorable, but unrelated, news events occurred within the same week, would we be able to remember their closeness in time 1 year later? The answer to these questions could be useful for constraining theories of memory for the times of past events, especially notions about the role of automatic processes (e.g., Aimone, Wiles, \& Gage, 2006; G. D. A. Brown \& Chater, 2001).

Relevant information about memory for temporal proximity comes from a number of laboratory studies of separation judgments (Hintzman \& Block, 1973; Hintzman, Summers, \& Block, 1975; Jackson, Michon, Boonstra, de Jonge, \& De Velde Harsenhorst, 1986; Underwood, 1977; Underwood \& Malmi, 1978). In a typical task, participants are presented with a long series of words and are later asked to judge the number of items that intervened between members of a test pair. These studies show that memory for the separation of unrelated pairs is very poor (Hintzman \& Block, 1973; Hintzman et al., 1975; Underwood \& Malmi, 1978). They also demonstrate that judgments of separations are much more accurate than chance expectations when the second item in a pair is identical to or is related to the first (Hintzman \& Block, 1973; Hintzman et al., 1975). Given the nature of the stimuli and the tasks, it seems likely that an automatic process, such as recursive reminding (Hintzman, 2004; Hintzman \& Block, 1973; Hintzman et al., 1975), is responsible for the accuracy of judgments of related items. Furthermore, the near-chance performance in judging the separations of unrelated items indicates that information about separations of unrelated events is not created automatically.

It is not clear, however, whether the findings of the laboratory studies "scale up" to the very long time scales of memory for life events or public events, because different mechanisms may be involved on the very different time scales. For example, automatic processes may create shortlasting information about temporal relations between related events, but such information may be lost over long spans of time (Friedman, 2007b). On the other hand, when one remembers public events or events from one's own life, the processes underlying reconstruction theories of memory for time (e.g., Friedman \& Wilkins, 1985; Hintzman, Block, \& Summers, 1973) may play an important role. These include noticing or being told about the temporal relations around the times that the second event occurred and inferring the relation at the time of testing.

Although there have been no studies designed to test memory for proximity on long time scales, there are incidental findings from a number of studies of memory for personal or news events. Some of these findings appear to support the ability to remember the temporal proximity of events that occurred within a few days of one another, even after long spans of time (Loftus \& Marburger, 1983; Shum, 1998). An example of this is flashbulb memory (R. Brown \& Kulik, 1977; Neisser, 1982; Pillemer, 1984; Yarmey $\&$ Bull, 1978). In other studies, when asked to estimate

W. J. Friedman, friedman@oberlin.edu 
the dates of news or personal events, participants have reported that they thought about other events that happened at about the same time as a target event (e.g., Baddeley, Lewis, \& Nimmo-Smith, 1978; Betz \& Skowronski, 1997; N. R. Brown, 1990; Burt, 1992b; Linton, 1975; Thompson, Skowronski, \& Betz, 1993).

However, these reports do not directly show that information about the proximity of events is normally available in memory, because special processes might be responsible: Relations between the two events could have been noticed at the time of encoding or could have been inferred at the time of recall (Friedman, 2007a). For example, two events could have been part of a set of actions in pursuit of a common goal. To rule out these explanations of the reports, it would be necessary to show that people are able to remember the temporal proximity of unrelated events. The few studies that include incidental findings about memory for unrelated events suggest that long-term memory for the temporal proximity of unrelated events is poor (see Friedman, 2007a).

We designed the present study to directly test memory for the proximity of unrelated events. Because we hoped to produce findings that would generalize to the long time scales of life events and public events, we chose retention intervals ranging from several months to several years. We used news events as our stimuli to make it possible to test a large number of participants. To further increase sensitivity, we selected participants with relatively homogeneous news exposure-Dutch adults who regularly followed the news - and we selected news events that were well recalled by a similar population.

In addition to addressing our main question about very long-term memory for the proximity of unrelated events, our study also provided an opportunity to collect data on judgments of the separations of events on long time scales. Although one can estimate the duration of events by judging the separation of the beginning and the end of the event (e.g., Burt \& Kemp, 1991) or the first and last occurrences of identical events (e.g., Douglas \& Blomfield, 1956; Pyles, Stolz, \& MacFarlane, 1935), the reverse is not always possible. Burt (1992a) asked participants about the duration of larger events that contained smaller events (filled) and about the duration of the time period between related events (unfilled events). He found that participants could estimate the duration of filled events better than the duration of unfilled events, suggesting that there is a difference between judging separation and judging duration. In the three experiments of the present study, we collected information about separation judgments of events that had occurred from 1 month to 6 years ago. If participants responded to the initial question that the two events had not occurred within 7 days of one another, we asked them a follow-up question, in which they chose from four separation categories.

\section{EXPERIMENT 1}

\section{Method}

Participants. The test was administered via the Internet (http:// memory.uva.nl/testpanel/chrono/) in Dutch. Participants could come into contact with the Web site through links on other Web sites, search engines, or promotion in traditional media, such as newspaper and magazine articles that included the Web address. We also invited participants who had taken other tests on the Web site, such as the Yearly News Memory Test (Janssen, Murre, \& Meeter, 2008) and the Galton-Crovitz test (Janssen, Chessa, \& Murre, 2005, 2006; Janssen \& Murre, 2008), to take this test as well.

Experiment 1 was conducted from October 2007 through April 2008. The final sample consisted of 960 Dutch participants between the ages of 18 and 80 years. Their average age was 49.25 years $(S D=13.35)$. There were more female $(65.0 \%)$ participants than male participants, and most participants $(60.6 \%)$ had the equivalent of a college or university degree.

Materials. From the ongoing Daily News Memory Test (Meeter, Murre, \& Janssen, 2005; Meeter, Ochtman, Janssen, \& Murre, 2010), we selected 52 news events that had been answered correctly by $90 \%$ of a reference population. Unrelated news events were paired in such a way that the difference in time of occurrence was 1 week or less $(n=8)$, between 1 week and 1 month $(n=5)$, between 1 month and 3 months $(n=5)$, between 3 months and 1 year $(n=5)$, or more than 1 year $(n=3)$. The retention interval of the most recent event of each pair ranged between 25 and 2,074 days at the beginning of the experiment, and the average interval was 2.63 years. The 26 event pairs, the dates of their occurrences, and their separations are shown in Appendix A (Pairs 1-26). Of course, exposure to a news story is not always a punctate event, and stories may be referred to in the media over some period of time. For this reason, the temporal parameters used to describe our stimuli can be considered to be only approximate.

Procedure. Participants were required to register before starting the test. They had to give their gender, date of birth, level of education, and how frequently they read a newspaper or watched the news on television. After participants read the instructions, they were given the 26 event pairs in random order. They were asked to check a box below each event if they did not know the event. Next, they were given one or two questions. They were first asked whether the two events had occurred in the same week (they had been told that the term week meant 7 days rather than the period from Monday to Sunday). If their answer was "yes," they proceeded to the next event pair; if their answer was "no," they were given four options on a second question about the separation between the events: less than 1 month (but more than 1 week), less than 3 months (but more than 1 month), less than 1 year (but more than 3 months), and more than 1 year. If a participant reported not knowing one or both events, he or she still had to guess the time difference between the events. After the participants had answered the questions about all event pairs, they were given their overall results and were briefly told about the purposes of the experiment.

\section{Results}

Given the considerations associated with Internet testing (e.g., Gosling, Vazire, Srivastava, \& John, 2004; Reips, 2000, 2002; Schmidt, 1997), several measures were undertaken to ensure quality control.

We omitted results for tests that were not completed within $20 \mathrm{~min}$. We also omitted results if participants had taken the test before, reported reading the newspaper or watching the news on the television fewer than three times a week, were younger than 18 years or older than 80 years, resided outside of the Netherlands, or had not heard of more than 9 of the 52 news events. The remaining participants $(N=960)$ took on average $8 \mathrm{~min} 24 \mathrm{sec}$ to complete the study. Participants in the final sample reported not knowing one or both of the news events on $4.3 \%$ of pairs, confirming that these news events were very well known by the sample. Exclusion of the pairs for which one or 
Table 1

Metrics of Accuracy in Detecting the Proximity of Same-Week Event Pairs (Hits, Misses, False Alarms, Correct Rejections, $d^{\prime}$, and Beta Criterion) and Overall Correlations Between Separation and Answer (Hierarchical Linear Modeling [HLM] Betas and Probability Levels) for Unrelated and Related Pairs in the Three Experiments

\begin{tabular}{|c|c|c|c|c|c|}
\hline \multirow[b]{2}{*}{ Pair Type } & \multirow{2}{*}{$\begin{array}{c}\text { Experiment } 1 \\
\text { Unrelated }\end{array}$} & \multicolumn{2}{|c|}{ Experiment 2} & \multicolumn{2}{|c|}{ Experiment 3} \\
\hline & & Related & Unrelated & Related & Unrelated \\
\hline Hits & .209 & .439 & .182 & .376 & .088 \\
\hline Misses & .791 & .561 & .818 & .624 & .912 \\
\hline False alarms & .123 & .139 & .150 & .089 & .043 \\
\hline Correct rejections & .877 & .861 & .850 & .911 & .957 \\
\hline$d^{\prime}$ & 0.349 & 0.932 & 0.130 & 1.032 & 0.367 \\
\hline$d^{\prime}$ beta & 1.160 & 1.090 & 1.040 & 1.350 & 1.720 \\
\hline HLM beta between true and judged separation & .056 & .480 & -.019 & .466 & .117 \\
\hline$p$ & .001 & .001 & .026 & .001 & .001 \\
\hline
\end{tabular}

both events were not recognized led to very small changes from the values reported below.

To answer our main question about whether people are able to remember the temporal proximity of unrelated events that happened close in time, we first analyzed responses to the initial question regarding whether the two events had occurred within the same week. Rows 1-6 of column 1 of Table 1 show the proportions of hits, misses, false alarms, and correct rejections, and $d^{\prime}$ and the beta associated with that $d^{\prime}$. The $d^{\prime}$ for accuracy in detecting the proximity of the same-week pairs in the initial question (0.349) shows that participants were very poor in detecting the proximity of unrelated same-week events.

Combining the results from the initial question and the follow-up question, one can examine participants' ability to judge the magnitude of intervals separating pairs of remembered events (see Figure 1). The combined separation judgments were analyzed by hierarchical linear modeling (HLM), a method that is similar to regression analyses but that appropriately treats nested designs such as the present one. Unlike regression analyses, HLM does not assume the independence of each individual's assessments of multiple stimuli. In the present analysis, judged separations (range 1-5) were predicted by the true separation in days. The results are shown in the last two rows of column 1 of Table 1. The beta from the HLM analysis is similar to a correlation coefficient, and, although significant, its magnitude shows that true separation accounted for less than $1 \%$ of within-subjects variance in judged separation.

To test whether this relation is influenced by how long ago the events occurred, we also examined whether there was an interaction between actual separations and the average retention interval of the paired events in predicting judgments. The interaction was significant $(p<.001)$ but

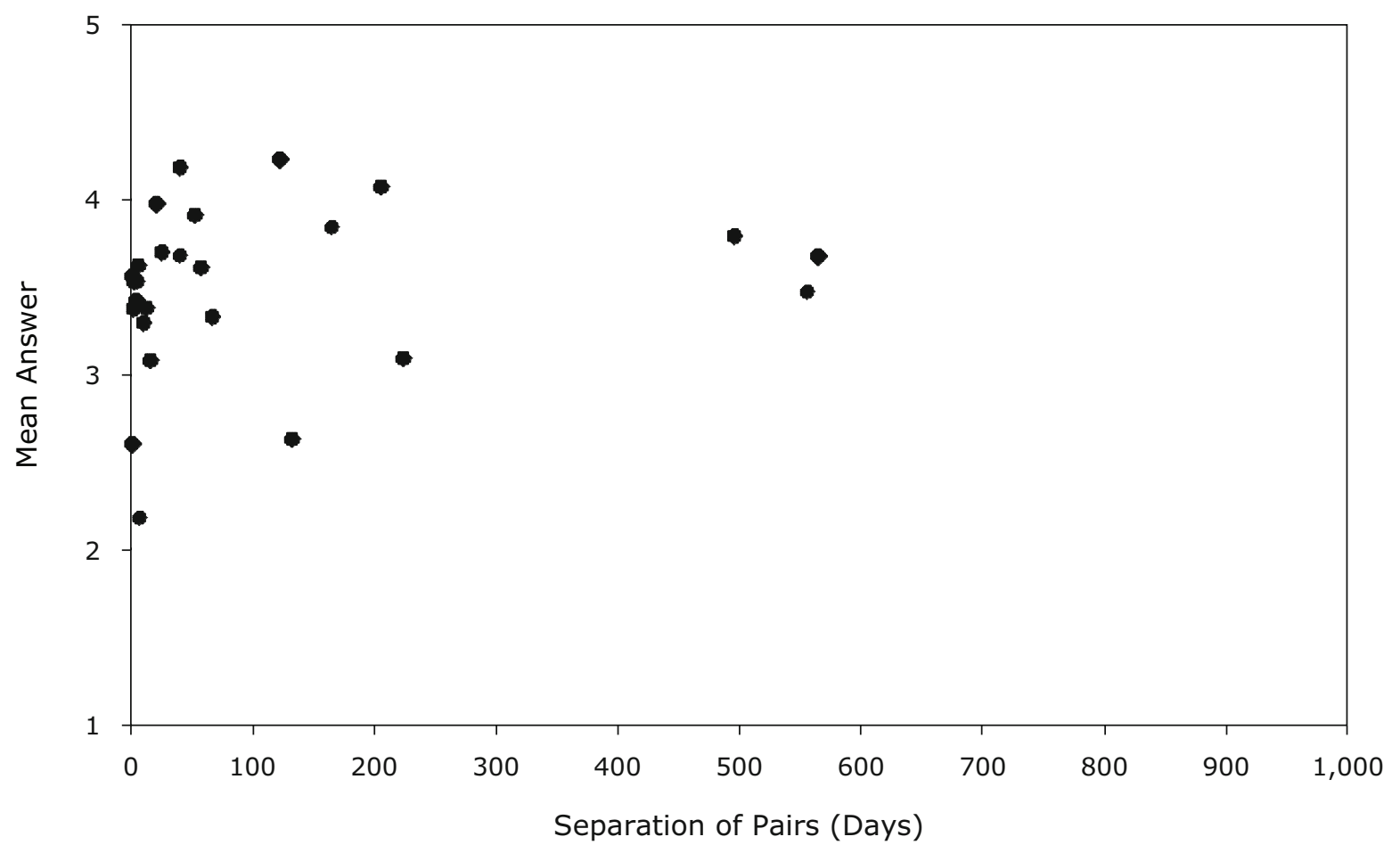

Figure 1. Mean answer (1-5) as a function of the separation for each pair of news events in Experiment 1. 
weak, accounting for less than $1 \%$ of within-subjects variance. This shows that, throughout the range of retention intervals sampled, participants were very poor in discriminating the separations of events.

\section{Discussion}

The present study was conducted to test people's ability to remember the temporal proximity of unrelated events. The public events sampled in the present study events had happened long enough ago that the results might generalize to autobiographical memories, with events ranging from about 1 month to about 6 years in the past. Furthermore, it was shown - by a recognition measure in this study and by a multiple-choice test administered to a similar population - that the events were very well remembered. The results showed that participants' ability to remember that two events had occurred at about the same time was very poor, with a $d^{\prime}$ of only 0.349 . We also found that the ability to judge temporal separations of events, using categories ranging from less than 1 week to more than 1 year, is very poor.

These results replicate earlier findings from laboratory studies, and they suggest that, on very long time scales, information about proximity and separations is not automatically stored. It is well established that adults are able to make differentiated judgments of when individual events happened on such time scales (Friedman, 1993, 2004; Skowronski, Walker, \& Betz, 2003). There is also considerable support that judgments of the times of events on long time scales depend on two processes - reconstruction and distance-based processes (Friedman, 2004). In reconstruction theories, information about times of occurrence is derived from the ordinary content of memories: Contextual and other information associated with an event (or provided in the event description) is used at the time of retrieval to infer when the event occurred. Distancebased theories assume that changes in the properties of memory with the passage of time-such as declines in trace strength (Hinrichs, 1970; Morton, 1968), the number of details that we remember about an event (N. R. Brown, Rips, \& Shevell, 1985), and the vividness of memories (Friedman, 1996, 2001)—make available information about how long ago an event occurred.

Neither of these processes implies a general ability to access information about the proximity or separations of unrelated pairs of events, as would be expected if automatic processes were important. The former would require, at the time of testing, an elaborate process, in which participants reconstruct the temporal location of each event and use this information to estimate the separation of the two. For theories incorporating distance-based processes, information about temporal separations is distinct only when ratios of the two distances in the past are relatively large - for example, one event occurred 2 months ago and the other occurred 1 year ago. There was only one such pair in the present study: Pair 24 in Appendix A has a separation of 496 days, and the more recent of the two news stories had occurred only about 6 months before the test. On this pair, participants were much more likely than on other pairs, whose more recent item was less than 1 year old, to choose the more-than-1-year category ( $p<.001$ by the binomial test). It appears that many participants' judgments that the two events were widely separated were based on the impressions that one event was relatively recent and the other was long ago.

\section{EXPERIMENT 2}

The use of unrelated events was important in Experiment 1 for distinguishing the use of automatic processes from reconstruction in memory for the temporal proximity of events. The probability that reconstruction would be used was slight in Experiment 1, because relations between two events were very unlikely to have been noticed around the time of encoding or to have been inferred at the time of recall. The very poor memory for proximity with these well-known, but unrelated, events would appear to pose a challenge to theories that presume that information relevant to temporal proximity is created through automatic processes. However, it is possible to argue that the poor performance in Experiment 1 resulted from participants' finding the task to be too difficult. We addressed this concern in Experiment 2 by including related pairs of events. If participants are able to judge the related pairs in Experiment 2 with some accuracy but still perform poorly on unrelated pairs, this criticism can be ruled out.

\section{Method}

Participants. Experiment 2 was conducted from April 2008 through November 2008. For the main part of Experiment 2, the final sample consisted of 749 Dutch participants between the ages of 18 and 80 years. Their average age was 52.02 years $(S D=13.48)$. The group consisted of more female $(66.4 \%)$ than male participants, and the majority $(60.6 \%)$ had the equivalent of a college or university degree.

A separate sample of 38 participants (who met the same inclusion criteria as those used for the main part of Experiment 2) was asked to judge the relatedness of the members of the related and unrelated pairs, as described below.

Procedure and Materials. The procedure of Experiment 2 was identical to the procedure of Experiment 1, except that the stimuli in Experiment 2 consisted of 40 event pairs, half of which were related and half of which were unrelated. We dropped 6 unrelated event pairs from the set used in the first experiment (Appendix A, Pairs 5, 6, 8, 12, 17, and 23) and added 20 new, related event pairs (Pairs 27-46). The two events in each of the related pairs shared the same protagonists, were the same kind of event, or had a causal relationship. The news events in the related pairs had also been answered correctly by $90 \%$ of a reference population in the Daily News Memory Test (Meeter et al., 2005; Meeter et al., 2010). The addition of 14 event pairs to the design caused the average completion time to increase to $13 \mathrm{~min} 2 \mathrm{sec}$.

The separate sample of 38 participants was asked to judge the relatedness of the members of the related and unrelated pairs, on a 5 -point scale, ranging from completely unrelated to very strongly related. The related event pairs were given higher relatedness ratings $(M=4.17, S D=1.26)$ than were the unrelated event pairs $(M=$ $1.12, S D=0.58)[t(37)=32.42, p<.001]$.

The 40 pairs were presented in random order. The related and unrelated event pairs were distributed similarly over the five separation intervals. There were 5 pairs of events from each group with a separation of 1 week or less, 4 pairs with a separation between 1 week and 1 month, 4 pairs with a separation between 1 and 3 months, 4 pairs with a separation between 3 months and 1 year, and 3 pairs with a separation of more than 1 year. The average retention interval of the related event pairs at the beginning of the experiment was 2.63 years, 


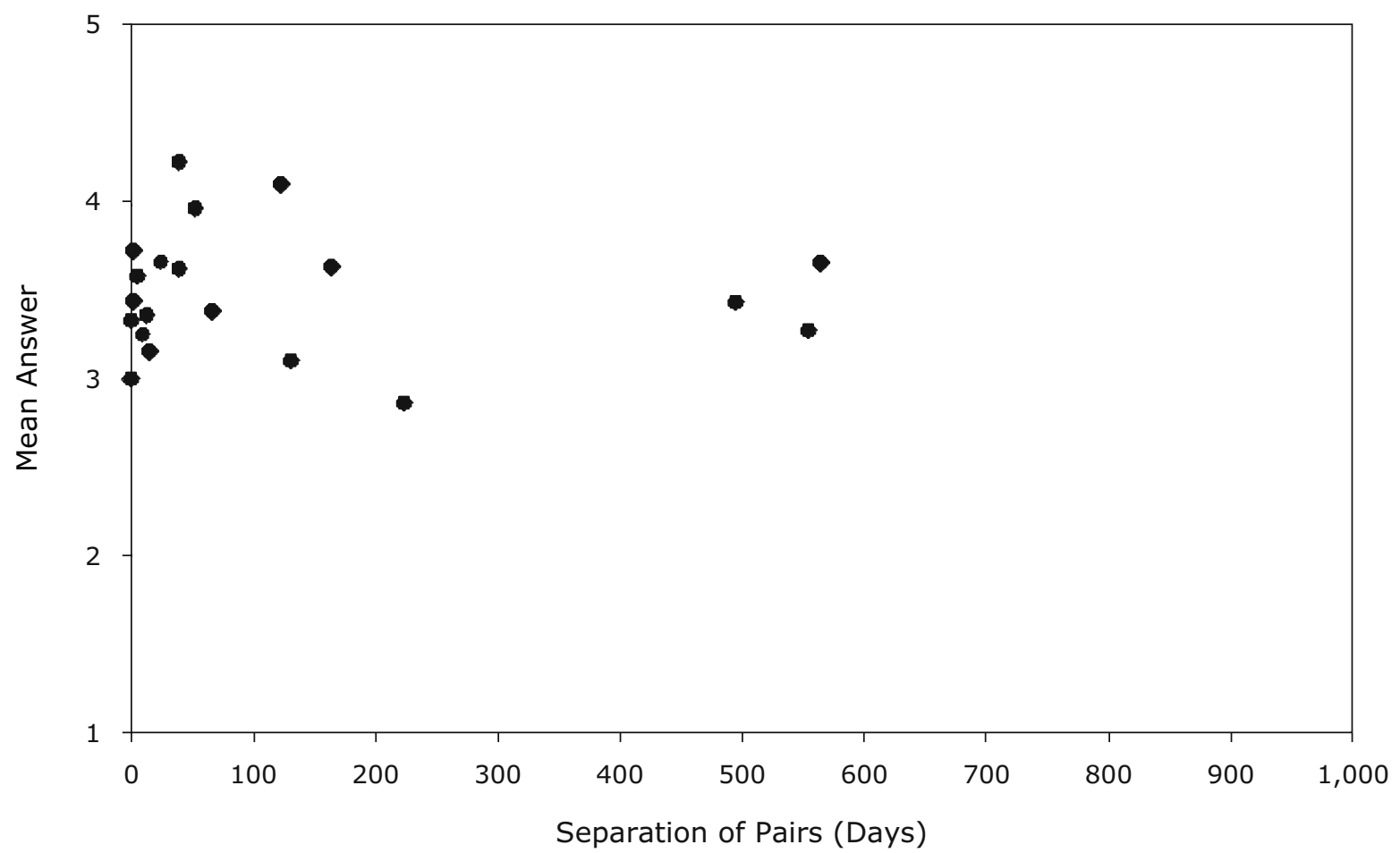

Figure 2. Mean answer (1-5) as a function of the separation for each unrelated pair of news events in Experiment 2.

and the average retention interval of the unrelated event pairs was 2.86 years. This difference was not significant $(p=.670)$.

\section{Results}

We omitted results for tests that were not completed within $30 \mathrm{~min}$. We also omitted results if participants had taken the test before, reported reading the newspaper or watching the news on the television fewer than three times a week, were younger than 18 years or older than 80 years, or resided outside of the Netherlands. Our criterion for dropping participants for poor recognition of events in this experiment was not having heard of more than 9 of the 80 news events. For the remainder of the sample $(N=749)$, participants reported not knowing one or both of the news events on $4.39 \%$ of pairs, repeating the finding of Experiment 1 that the stimulus events were very well known by our sample. The related event pairs were recognized as often as the unrelated event pairs $(95.4 \%$ and $95.8 \%, p=$ .836).

As in Experiment 1, we addressed our primary questions about the ability to remember the temporal proximity of events that happened close in time by computing $d^{\prime}$ values for responses to the first question - whether the two events had occurred within 7 days of one another (see rows 1-6 of the data columns 2-3 of Table 1). The $d^{\prime}$ values show that participants were very poor in judging whether unrelated pairs had occurred close in time, but they were able to make differentiated judgments for related pairs.

Also as in Experiment 1, we measured the ability to judge the magnitude of intervals separating pairs of events by combining the results from the initial and the follow-up question and using answer category (1-5) as the dependent measure. Figure 2 shows the relation between actual and judged separations for the unrelated pairs; Figure 3 shows this relation for related pairs. A preliminary HLM analysis showed that the relation between true and judged separation interacted with whether pairs were related or unrelated $(p<.001)$, so the main analyses were conducted separately for the two types of pairs. The beta values and probability levels for HLM analyses of related and unrelated pairs are given in the last two rows of data columns 2-3 of Table 1. As in Experiment 1, true separation was a very poor predictor of separation judgments for the unrelated pairs. However, participants' judgments of the related pairs were substantially related to their actual separations.

For unrelated pairs, there was also a weak interaction between true separation and mean retention interval, accounting for less than $1 \%$ of within-subjects variance $(p<.001)$. A slightly larger, but still very weak, interaction between true separation and mean retention interval was found for the related pairs $[t(14,972)=17.383, p<$ $.001, \beta=-.1214]$.

\section{Discussion}

Participants' ability to judge the proximity and separations of related events with considerable accuracy indicates that the difficulty of the choice task was not the reason for poor performance in Experiment 1. We can conclude that the poor performance found in Experiment 1 is the result of participants' having little information available to judge the proximity and separations of unrelated event pairs.

The findings also reveal that there are conditions under which differentiated judgments can be made, and this raises the question of what processes allow people 


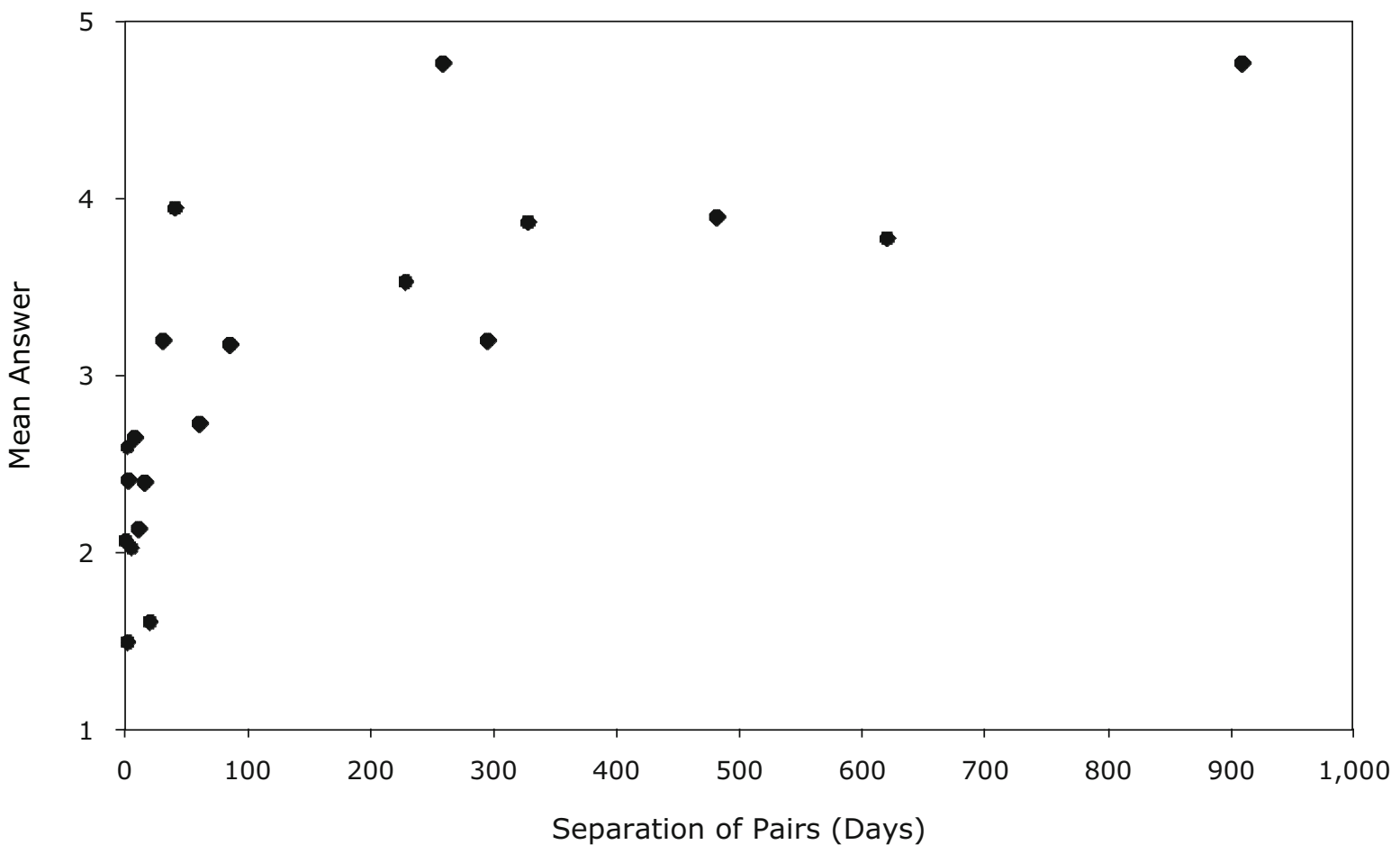

Figure 3. Mean answer (1-5) as a function of the separation for each related pair of news events in Experiment 2.

to judge with some accuracy the proximity and separations of related events that happened several months or years ago. The processes underlying reconstruction theories (e.g., Friedman \& Wilkins, 1985; Hintzman et al., 1973) provide one explanation. These processes include noticing or being told about the temporal relations around the times that the second event occurred and inferring the relation at the time of testing. In the conditions of this experiment, it seems likely that relations were often noticed around the times of the events. For example, for one of the related pairs, the capture of British hostages in 2007 by Iranian forces and the hostages' subsequent release, many participants may have remembered that the crisis was resolved relatively quickly, and news reports probably mentioned this specifically. For other related pairs, such as the jailing and release of Paris Hilton, semantic knowledge about the approximate duration of a sentence for drunk driving could have been exploited at the time of the test session. The processes posited in another theory, recursive-reminding theory (Hintzman, 2004; Hintzman \& Block, 1973; Hintzman et al., 1975), could also explain superior performance on related pairs, although there is reason to believe that long-term memory for the relations is possible only if the reminding leads to active processing of the temporal relation (Friedman, 2007b).

\section{EXPERIMENT 3}

Experiment 2 revealed large differences in the detection of proximity and separation judgments between pairs that were selected to be related and those selected to be unrelated. However, because mostly different news events were used for the two kinds of pairs, it could be argued that intrinsic differences between the items used in the two sets - not the relatedness of pairs - were responsible for the greater accuracy of related pairs. This would limit our ability to attribute the ability to make these types of temporal judgments to processes associated with the relatedness of pairs: reconstruction processes or recursive reminding. We addressed this concern in Experiment 3, in which the same events appeared in both related and unrelated pairs.

Another limitation of both Experiments 1 and 2 was that participants' judgments on the initial and follow-up questions provided the only evidence about what processes were used. We therefore asked participants in Experiment 3 to report the methods that they used to arrive at their answers for each pair. On the basis of reconstruction theories, we expected that reports that participants remembered that the two events occurred around the same time and that they used deduction to judge the amount of time separating events in a pair would be more common for related than for unrelated pairs. Because reconstruction seldom helps with unrelated pairs, we also predicted that reports indicative of guessing would be more common for unrelated pairs. Finally, to provide another source of information about how participants performed the tasks, they were asked to rate their confidence in their judgments for each pair. We expected greater confidence in proximity and separation judgments for the related pairs - for which reconstruction could be used - than for the unrelated pairs.

\section{Method}

Participants. Experiment 3 was conducted from December 2008 through April 2009. The final sample consisted of 200 Dutch par- 
ticipants between the ages of 18 and 80 years. Their average age was 54.11 years $(S D=12.03)$. There were more female $(62.0 \%)$ than male participants, and most participants $(58.5 \%)$ had the equivalent of a college or university degree.

Materials. We selected 18 related event pairs, which were also rearranged to form 18 unrelated event pairs and were distributed over the same five separation intervals. There were 5 pairs of events from each pair type with a separation of 1 week or less, 3 pairs with a separation between 1 week and 1 month, 3 pairs with a separation between 1 and 3 months, 4 pairs with a separation between 3 months and 1 year, and 3 pairs with a separation of more than 1 year. The 36 related and unrelated event pairs, the dates of their occurrences, and their separations are shown in Appendix B.

The retention interval of the most recent event of each pair ranged between 76 and 1,640 days at the beginning of the experiment. Because all events were used in both conditions, the retention intervals of the related event pairs at the beginning of the experiment $(M=$ 2.06 years) were not different from the retention intervals of the unrelated event pairs $(M=2.10$ years; $p=.937)$.

Procedure. The procedure of Experiment 3 was similar to that of the first and second experiments, although three new questions for each pair were added. The first was the relatedness judgment described for the separate sample in the Method section of Experiment 2. This question was asked before the participants indicated whether the two events had occurred in the same week. The second new question was given after participants had selected the appropriate separation interval. We asked them to rate their confidence in their answer on a 5-point scale that ranged from very uncertain (1) to very confident (5). This was followed by the third new question, in which participants were asked to select for each pair the kind of temporal information that they had used to determine the time between the two events. The participants chose from eight options: (1) They recalled that the two events occurred close in time, (2) they used the times of other news stories that happened close to the events, (3) they recalled the exact dates of the events, (4) they remembered the personal circumstances in which they first heard about the events, (5) they remembered the general period in which the events had happened, (6) they used the strength of memories to decide how long ago the events happened, (7) they logically deduced the time between the events, and (8) their answer was a complete guess. The addition of these three questions for each event pair caused the average completion time to increase to $25 \mathrm{~min} 8 \mathrm{sec}$. Because the experiment took longer to complete than the previous experiments, the time limit was extended to $60 \mathrm{~min}$.

\section{Results}

We omitted results for tests that were not completed within $60 \mathrm{~min}$. We also omitted results if participants had taken the test before, reported reading the newspaper or watching the news on the television fewer than three times a week, were younger than 18 years or older than 80 years, or resided outside of the Netherlands. Our criterion for dropping participants for poor recognition of events in this experiment was, again, not having heard of more than nine of the news events. For the remainder of the sample $(N=$ 200), participants reported not knowing one or both of the news events on $5.32 \%$ of pairs, repeating the finding of Experiments 1 and 2 that the stimulus events were very well known by our sample. The events were recognized as frequently when they were presented in related pairs $(95.8 \%)$ as when they were presented in unrelated pairs $(93.6 \%, p=.229)$.

Contiguity and separation judgments. As in Experiments 1 and 2, our principle question about detecting the proximity of same-week events was addressed by computing $d$ 's (see rows 1-6 of the last two data columns of Table 1). The results show that detection of proximity was very poor for unrelated pairs and was much better for related pairs.

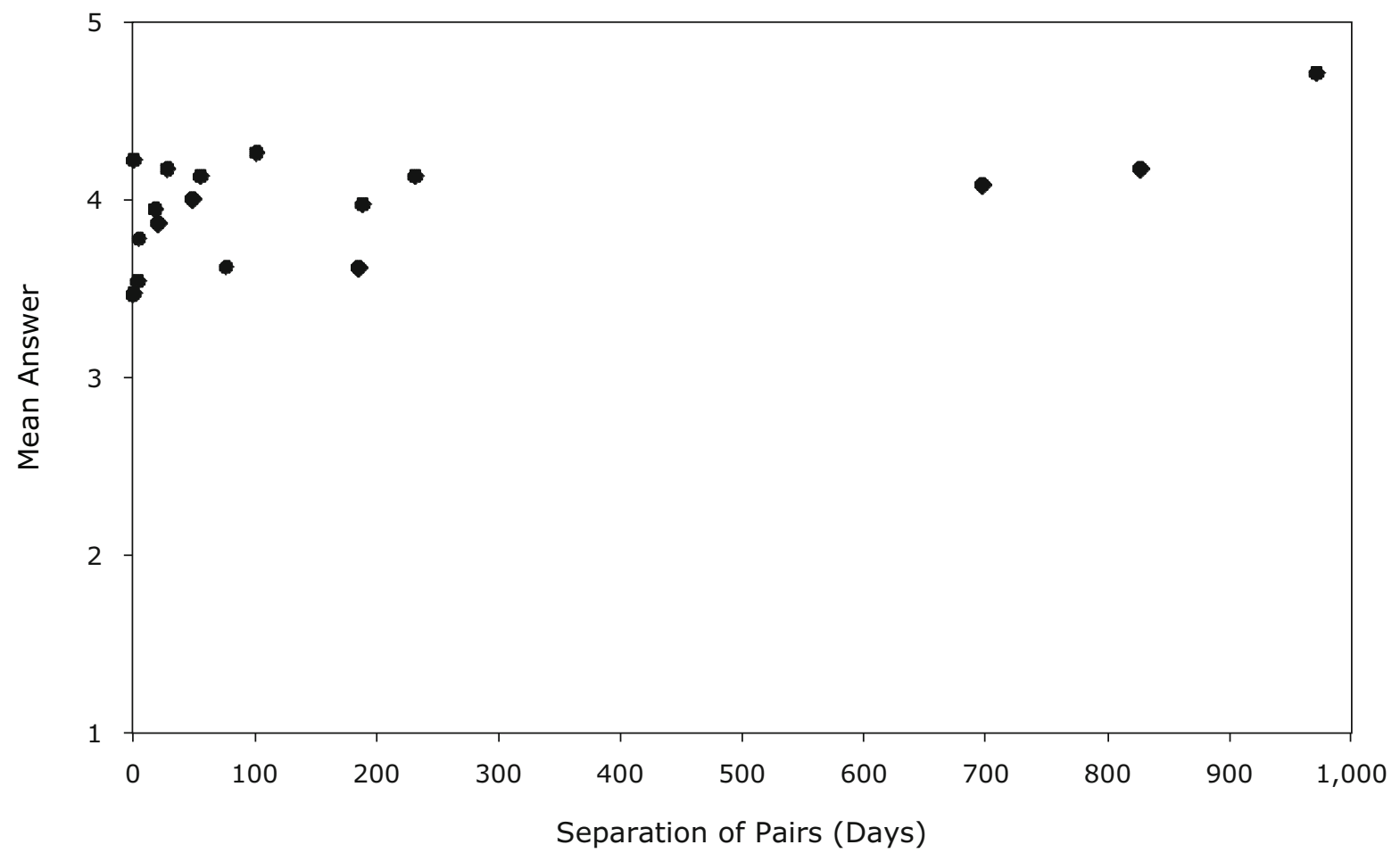

Figure 4. Mean answer (1-5) as a function of the separation for each unrelated pair of news events in Experiment 3. 


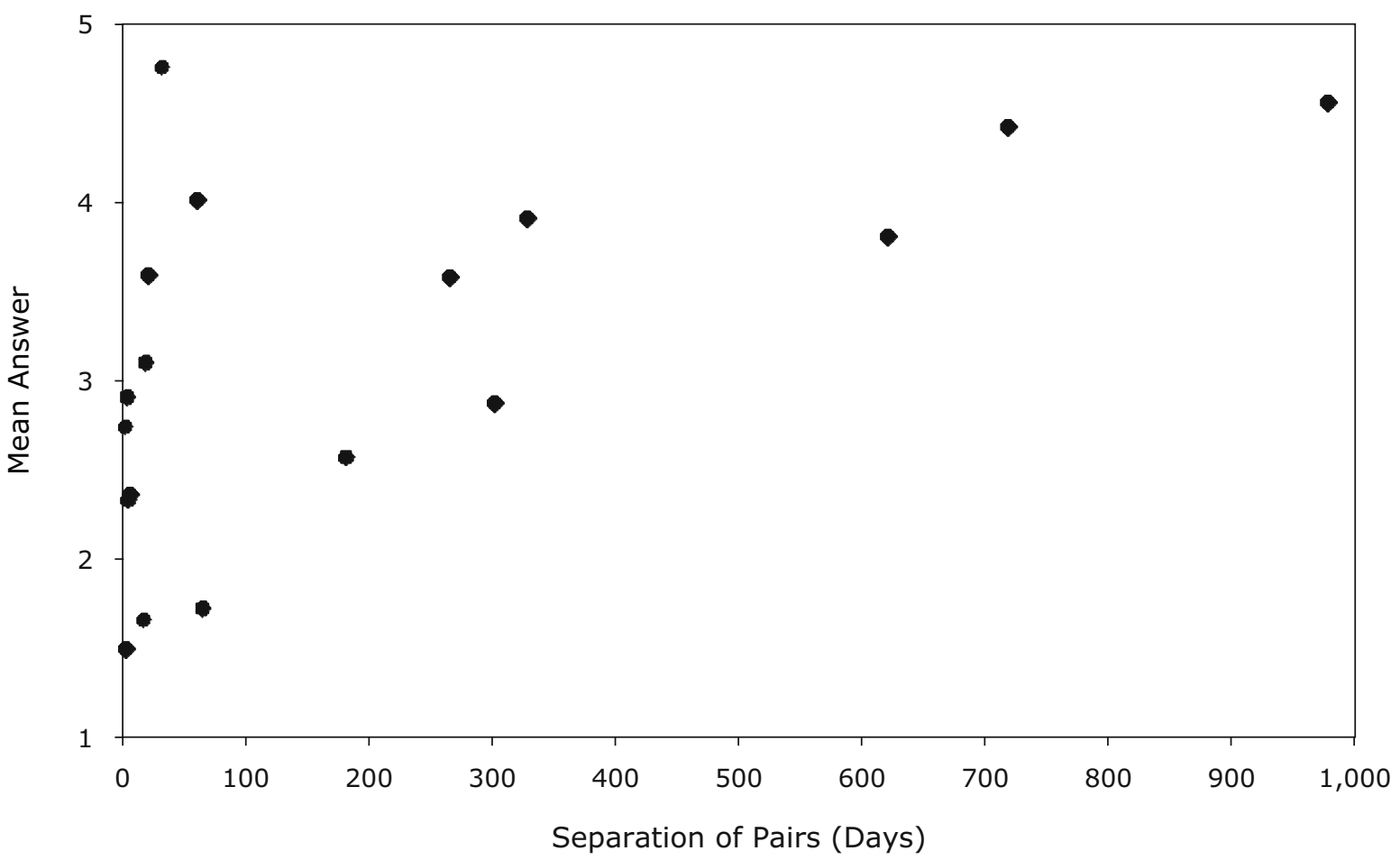

Figure 5. Mean answer (1-5) as a function of the separation for each related pair of news events in Experiment 3.

We addressed our other questions about the ability to make differentiated judgments of the time intervals separating pairs of events by combining responses to the first and the follow-up questions. Figure 4 shows the relation between actual and judged separations for the unrelated pairs. Figure 5 shows this relation for related pairs. As was the case in Experiment 2, a preliminary HLM analysis showed that the relation between true and judged separation interacted with whether pairs were related or unrelated $(p<.001)$, so the main analyses were again conducted separately for the two types of pairs. The results of HLM analyses in the last two rows of the last two columns of Table 1 replicate the findings of Experiment 2: There was considerable accuracy for related pairs, but judgments of the separations of unrelated pairs were poor.

For unrelated pairs, there was a weak interaction between true separation and mean retention interval $[t(3,595)=3.15, p=.002, \beta=-.0880]$. The related pairs also showed a weak interaction between true separation and mean retention interval $[t(3,595)=-2.69, p=$ $.008, \beta=-.1006]$.

Judgments of relatedness and confidence. We tested participants' agreement with our categorization of pairs as related or unrelated by asking them to rate the relatedness of each pair. Mean ratings on the 5-point scale were 1.11 $(S D=0.29)$ for the unrelated pairs and $4.09(S D=0.73)$ for the related pairs. A two-way ANOVA showed that this difference was extremely strong and reliable $[F(1,1990)=$ $\left.17,045.76, p<.001, \eta_{\mathrm{p}}^{2}=.90\right]$. Significant, but small, effects of true separation category (from within the same week to more than 1 year; $\left.\eta_{\mathrm{p}}^{2}=.10\right)$ and its interaction with relatedness category $\left(\eta_{\mathrm{p}}^{2}=.07\right)$ were also found $(p \mathrm{~s}<$
.001). For related pairs, relatedness ratings declined somewhat with increasing separations, whereas no clear pattern was evident for the unrelated pairs. Similar results were obtained when analyses were performed with true separation categories replaced by judged separation categories.

Participants also rated their confidence in their temporal judgments on a 5-point scale. As we predicted, greater confidence was placed in judgments of related than in judgments of unrelated event pairs $[F(1,1990)=629.64$, $\left.p<.001, \eta_{\mathrm{p}}^{2}=.24\right]$. The means for the related and unrelated pairs are $3.43(S D=0.75)$ and $2.54(S D=0.94)$, respectively. The effects of separation category $\left(\eta_{\mathrm{p}}^{2}=.10\right)$ and its interaction with relatedness $\left(\eta_{\mathrm{p}}^{2}=.04\right)$ were also significant $(p s<.001)$, but the patterns are not easily described. A two-way ANOVA performed with judged separation category replacing true separation category produced similar results. It is worth noting, however, the large difference in the mean confidence when unrelated pairs were judged to be within 1 week $(1.84, S D=0.95)$ and when related pairs were judged to be from the same week $(3.50, S D=0.97)$.

Method reports. Table 2 shows the mean frequency of selecting each of the eight method categories for the 18 unrelated and 18 related event pairs. Included are the results of eight ANOVAs of proportions of responses within the five true separation categories, with related versus unrelated pairs and true separation category as the two within-subjects factors. Data rows 2-4 in Table 2 show that three of the methods (related events, exact dates, personal circumstances) were rarely reported. General period and strength of the memories were used with approximately the same frequency in both kinds of pairs. Of the remainder, 
Table 2

Mean Frequency of Use of the Eight Reported Methods for Unrelated and Related Event Pairs and Results of ANOVAs Testing Relatedness, Separation, and Their Interaction in Experiment 3

\begin{tabular}{|c|c|c|c|c|c|c|c|}
\hline \multirow[b]{2}{*}{ Method } & \multicolumn{2}{|c|}{ Unrelated } & \multicolumn{2}{|c|}{ Related } & \multirow[b]{2}{*}{ Relatedness $\eta_{\mathrm{p}}^{2}$} & \multirow[b]{2}{*}{ Separation $\eta_{\mathrm{p}}^{2}$} & \multirow[b]{2}{*}{ Interaction $\eta_{\mathrm{p}}^{2}$} \\
\hline & $M$ & $S D$ & $M$ & $S D$ & & & \\
\hline Recalled proximity & 0.35 & 1.09 & 2.39 & 2.51 & $.105^{* * *}$ & $.078^{* * *}$ & $.059^{* * *}$ \\
\hline Other events & 0.24 & 1.06 & 0.24 & 1.08 & .000 & .002 & .001 \\
\hline Exact dates & 0.04 & 0.22 & 0.08 & 0.31 & .001 & .001 & .000 \\
\hline Personal circumstances & 0.38 & 0.84 & 0.24 & 0.68 & $.003^{*}$ & $.005^{*}$ & $.005^{*}$ \\
\hline General period & 3.22 & 3.76 & 3.05 & 3.22 & .000 & $.013^{* * *}$ & $.009^{* *}$ \\
\hline Strength & 4.71 & 4.25 & 4.65 & 4.33 & .000 & $.012^{* * *}$ & $.012^{* * *}$ \\
\hline Deduction & 1.98 & 2.82 & 5.10 & 3.47 & $.112^{* * *}$ & $.007^{* *}$ & $.010^{* * *}$ \\
\hline Complete guess & 7.08 & 4.46 & 2.24 & 2.71 & $.200^{* * *}$ & $.054^{* * *}$ & $.021^{* * *}$ \\
\hline
\end{tabular}

two methods-remembering that the two events occurred close in time and deduction - were reported significantly more often for related than for unrelated pairs, whereas guessing was reported more frequently for unrelated pairs. The accompanying separation and interaction effects for the first method - remembering proximity - can be described as follows: For the related pairs, this category was used mainly for pairs from the same week or month, and separation category had little effect for unrelated pairs. The patterns underlying the separation and interaction effects for deduction and guessing are not easy to interpret; deduction was reported most often for the fifth separation category for the unrelated pairs and most often for the second separation category for the related pairs, whereas guessing was reported somewhat less often for the second and fifth separation categories for the unrelated and related pairs. The remaining separation and interaction effects are very weak, explaining $1 \%$ or less of variance.

Of particular interest are the methods reported for the same-week pairs. For unrelated events, the proportions of the eight methods, in the order listed in Table 2, are 2.4\%, $0.8 \%, 0.2 \%, 1.0 \%, 15.5 \%, 24.9 \%, 9.1 \%$, and $46.1 \%$. For related events, the proportions are $21.4 \%, 1.3 \%, 0.3 \%$, $0.6 \%, 13.8 \%, 21.6 \%, 26.9 \%$, and $14.2 \%$. These values show that recalling the proximity was common for related pairs (.214) but was very rare for unrelated events (.024). The difference suggests that choosing this first method category did not reflect the use of an automatic process but rather indicated the use of processes that depended on their relatedness. Deduction was also substantially more frequent for related same-week pairs (.269) than for unrelated same-week pairs (.091), whereas guessing was more than three times as frequent in unrelated (.461) than in related (.142) pairs.

\section{Discussion}

As in the previous experiments, participants in Experiment 3 were very poor in detecting the temporal proximity of unrelated pairs and were substantially more accurate for related pairs. In addition, joint analyses of the first and second questions showed that separation judgments were again more accurate for related than for unrelated pairs. This shows that the findings of Experiment 2 were not the result of a confounding between the relatedness of pairs and their difficulty.
We also found that participants had substantially greater confidence in their judgments for the related than for the unrelated pairs, providing further evidence that different processes were often used for the two. These differences between unrelated and related pairs are consistent with the predictions of reconstruction theories and are not consonant with theories based on automatic processes.

The method-report data also provide support for the use of different processes for the two types of pairs. First, we found that, for the unrelated pairs, the use of the two longest separation categories was often associated with guessing. Coupled with participants' inaccuracy in judging the separations of unrelated pairs in all three experiments, this indicates that, when participants had no information about relative times of occurrence, they chose wider separation categories. Perhaps most important, participants seldom reported that they recalled that two unrelated events had occurred close in time, but this was a commonly reported method for related same-week pairs. These findings contradict the view that an automatic process, at least one that does not depend on relatedness, creates information that indicates that the proximal events occurred close together. For related pairs, participants apparently were able to remember that the events occurred closely in time or were able to reconstruct their temporal proximity. We also confirmed the prediction that participants were more likely to report deduction for related than for unrelated pairs. Reports of deduction were common for answers in all separation categories, indicating that reconstruction plays an important role in separation as well as in contiguity judgments. The use of reconstruction in this task is similar to the processes that participants appeared to use in Burt and Kemp's (1991) study of the duration of temporally extended news events.

In addition, participants' reports that they used the strength of memories to decide how long ago the events had happened were found about equally often for related and unrelated pairs. Distance-based theories of memory for time rely on automatic processes, so this finding would be expected under these theories. In addition, distance reports were more frequent when participants chose greater separation categories, and this was true for both unrelated and related pairs. Participants may have understood that distance information is useful when events are widely separated: When the memory of one event is strong and 
the memory of another event is weak, the time between the two events must be long.

\section{GENERAL DISCUSSION}

We conducted the present study to assess people's ability to recall, over long periods of time, the temporal proximity of events that had occurred within days of one another. We used events that had happened long enough ago to be representative of the ages of many autobiographical memories, ranging from about 1 month to about 6 years in the past. Furthermore, it was shown that the events were very well remembered - by a recognition measure in this experiment and by a multiple-choice test administered to a similar population (Meeter et al., 2005; Meeter et al., 2010). In all three experiments, we found that memory for proximity is very poor for pairs of events that had occurred close in time but were unrelated to one another. In contrast, when two proximal events are meaningfully related, people can often remember their closeness in time.

Our secondary findings-concerning the ability to judge the separations of events - resemble those from laboratory studies of separation judgments (Hintzman \& Block, 1973; Hintzman et al., 1975; Jackson et al., 1986; Underwood, 1977; Underwood \& Malmi, 1978). As mentioned in the introduction, it is unlikely that reconstruction played an important role in the judgments in laboratory studies, and the automatic processes posited in recursive-reminding theory seem to be a better explanation. However, recursive reminding alone was probably not responsible for accurate separation judgments of related pairs on the much longer time scales of the present experiments. A recent experiment (Friedman, 2007b), mentioned earlier, showed that people are poor at remembering the order of two related events when those relations cannot be reconstructed at the time of recall. Probably, long-term memory for order and separations requires active processing of the relations near the times that the events occurred or reconstruction of the temporal relations at the time of recall.

It is important to acknowledge the limits of the findings of the present study. Because we chose news events as our stimuli, it was not possible to know precisely when participants first learned about the events and whether they heard or read references to them at other times. This means that the temporal parameters that we used to describe the stimuli are only approximate. The use of naturally occurring events also means that we are unable to isolate the specific processes that led to greater accuracy for the related pairs. In laboratory studies of memory for lists of words, few processes - other than reminding — can account for the greater accuracy on related than on unrelated pairs. With news events, these may include not only reconstruction - for which we provided some supportbut also memory for the fact that the two events were mentioned together and that their relation was discussed. Finally, although we chose events that happened long ago, in an effort to approximate the long time scales of many autobiographical memories, there are many reasons why memory for the proximity or separation of a particular pair of life events could be better (or worse).

\section{AUTHOR NOTE}

We thank Nancy Darling for her advice and help with statistical analyses, Patricia deWinstanley and David Rubin for helpful comments, and Jaap Murre and Martijn Meeter, the founders of the Web site used to conduct this research. The present study was supported by a Rubicon Grant from the Netherlands Organization for Scientific Research (NWO) to S.M.J.J. S.M.J.J. is now at the Department of Psychology, Hokkaido University. Address correspondence concerning this article to W. J. Friedman, Department of Psychology, Oberlin College, Severance Laboratory, Oberlin, OH 44074 (e-mail: friedman@oberlin.edu).

\section{REFERENCES}

Aimone, J. B., Wiles, J., \& Gage, F. H. (2006). Potential role for adult neurogenesis in the encoding of time in new memories. Nature Neuroscience, $9,723-727$.

Baddeley, A. D., Lewis, V., \& Nimmo-Smith, I. (1978). When did you last . . . ? In M. M. Gruneberg, P. E. Morris, \& R. N. Sykes (Eds.), Practical aspects of memory (pp. 78-83). London: Academic Press.

Betz, A. L., \& Skowronski, J. J. (1997). Self-events and other-events: Temporal dating and event memory. Memory \& Cognition, 25, 701714.

Brown, G. D. A., \& Chater, N. (2001). The chronological organization of memory: Common psychological foundations for remembering and timing. In C. Hoerl \& T. McCormack (Eds.), Time and memory: Issues in philosophy and psychology (pp. 77-110). Oxford: Oxford University Press.

Brown, N. R. (1990). Organization of public events in long-term memory. Journal of Experimental Psychology: General, 119, 297-314.

Brown, N. R., Rips, L. J., \& Shevell, S. K. (1985). The subjective dates of natural events in long-term memory. Cognitive Psychology, 17, 139-177.

Brown, R., \& Kulik, J. (1977). Flashbulb memories. Cognition, 5, 7399.

BURT, C. D. B. (1992a). Reconstruction of the duration of autobiographical events. Memory \& Cognition, 20, 124-132.

BurT, C. D. B. (1992b). Retrieval characteristics of autobiographical memories: Event and date information. Applied Cognitive Psychology, 6, 389-404.

BURT, C. D. B., \& KEMP, S. (1991). Retrospective duration estimation of public events. Memory \& Cognition, 19, 252-262.

Douglas, J. W. B., \& Blomfield, J. M. (1956). The reliability of longitudinal surveys. Milbank Memorial Fund Quarterly, 34, 227-252.

Friedman, W. J. (1993). Memory for the time of past events. Psychological Bulletin, 113, 44-66. doi:10.1037/0033-2909.113.1.44

FriedMAN, W. J. (1996). Distance and location processes in memory for the times of past events. In D. L. Medin (Ed.), The psychology of learning and motivation (Vol. 35, pp. 1-41). San Diego: Academic Press.

FRIEDMAN, W. J. (2001). Memory processes underlying humans' chronological sense of the past. In C. Hoerl \& T. McCormack (Eds.), Time and memory: Issues in philosophy and psychology (pp. 139-167). Oxford: Oxford University Press.

Friedman, W. J. (2004). Time in autobiographical memory. Social Cognition, 22, 591-605. doi:10.1521/soco.22.5.591.50766

Friedman, W. J. (2007a). Comment on "Potential role for adult neurogenesis in the encoding of time in new memories." Hippocampus, 17, 503-504.

FRIEDMAN, W. J. (2007b). The role of reminding in long-term memory for temporal order. Memory \& Cognition, 35, 66-72.

Friedman, W. J., \& WiLKINS, A. J. (1985). Scale effects in memory for the time of events. Memory \& Cognition, 13, 168-175.

Gosling, S. D., Vazire, S., Srivastava, S., \& John, O. P. (2004). Should we trust Web-based studies? A comparative analysis of six preconceptions about Internet questionnaires. American Psychologist, 59, 93-104.

HinRICHS, J. V. (1970). A two-process memory strength theory for judgment of recency. Psychological Review, 77, 223-233. 
Hintzman, D. L. (2004). Judgment of frequency versus recognition confidence: Repetition and recursive reminding. Memory \& Cognition, 32, 336-350

Hintzman, D. L., \& Block, R. A. (1973). Memory for the spacing of repetitions. Journal of Experimental Psychology, 99, 70-74.

Hintzman, D. L., Block, R. A., \& Summers, J. J. (1973). Contextual associations and memory for serial position. Journal of Experimental Psychology, 97, 220-229.

Hintzman, D. L., Summers, J. J., \& Block, R. A. (1975). Spacing judgments as an index of study-phase retrieval. Journal of Experimental Psychology: Human Learning \& Memory, 1, 31-40.

Jackson, J. L., Michon, J. A., Boonstra, H., De Jonge, D., \& De Velde Harsenhorst, J. (1986). The effect of depth of processing on temporal judgment tasks. Acta Psychologica, 62, 199-210.

Janssen, S. M. J., Chessa, A. G., \& Murre, J. M. J. (2005). The reminiscence bump in autobiographical memory: Effects of age, gender, education, and culture. Memory, 13, 658-668. doi:10.1080/ 09658210444000322

Janssen, S. M. J., Chessa, A. G., \& Murre, J. M. J. (2006). Memory for time: How people date events. Memory \& Cognition, 34, 138-147.

Janssen, S. M. J., \& Murre, J. M. J. (2008). Reminiscence bump in autobiographical memory: Unexplained by novelty, emotionality, valence, or importance of personal events. Quarterly Journal of Experimental Psychology, 61, 1847-1860. doi:10.1080/ 17470210701774242

Janssen, S. M. J., Murre, J. M. J., \& Meeter, M. (2008). Reminiscence bump in memory for public events. European Journal of Cognitive Psychology, 20, 738-764. doi:10.1080/09541440701554409

Linton, M. (1975). Memory for real-world events. In D. A. Norman \& D. E. Rumelhart (Eds.), Explorations in cognition (pp. 376-404). San Francisco: Freeman

Loftus, E. F., \& Marburger, W. (1983). Since the eruption of Mt. St. Helens, has anyone beaten you up? Improving the accuracy of retrospective reports with landmark events. Memory \& Cognition, 11, 114-120.

Meeter, M., Murre, J. M. J., \& Janssen, S. M. J. (2005). Remembering the news: Modeling retention data from a study with 14,000 participants. Memory \& Cognition, 33, 793-810.
Meeter, M., Ochtman, D. J. C., Janssen, S. M. J., \& Murre, J. M. J. (2010). Of sports and politics: Predicting category-specific retention of news events from demographic variables. European Journal of Cognitive Psychology, 22, 117-129.

Morton, J. (1968). Repeated items and decay in memory. Psychonomic Science, 10, 219-220.

NeIsser, U. (1982). Snapshots or benchmarks? In U. Neisser (Ed.), Memory observed: Remembering in natural contexts (pp. 43-48). San Francisco: Freeman.

Pillemer, D. B. (1984). Flashbulb memories of the assassination attempt on President Reagan. Cognition, 16, 63-80.

Pyles, M. K., Stolz, H. R., \& MacFarlane, J. T. (1935). The accuracy of mothers' reports on birth and developmental data. Child Development, 6, 165-176.

REIPS, U.-D. (2000). The Web experiment method: Advantages, disadvantages, and solutions. In M. H. Birnbaum (Ed.), Psychological experiments on the Internet (pp. 89-118). San Diego: Academic Press.

REIPS, U.-D. (2002). Standards for Internet-based experimenting. Experimental Psychology, 49, 243-256.

Schmidt, W. C. (1997). World-Wide Web survey research: Benefits, potential problems, and solutions. Behavior Research Methods, Instruments, \& Computers, 29, 274-279.

Shum, M. S. (1998). The role of temporal landmarks in autobiographical memory processes. Psychological Bulletin, 124, 423-442.

Skowronski, J. J., WALKer, W. R., \& Betz, A. L. (2003). Ordering our world: An examination of time in autobiographical memory. Memory, 11, 247-260

Thompson, C. P., Skowronski, J. J., \& Betz, A. L. (1993). The use of partial temporal information in dating personal events. Memory \& Cognition, 21, 352-360.

Underwood, B. J. (1977). Temporal codes for memories: Issues and problems. Hillsdale, NJ: Erlbaum.

Underwood, B. J., \& Malmi, R. A. (1978). An evaluation of measures used in studying temporal codes for words within a list. Journal of Verbal Learning \& Verbal Behavior, 17, 279-293.

YARMeY, A. D., \& Bull, M. P., III (1978). Where were you when President Kennedy was assassinated? Bulletin of the Psychonomic Society, 11, 133-135.

\section{APPENDIX A}

\begin{tabular}{|c|c|c|c|c|c|}
\hline Pair & Event 1 & Date 1 & Event 2 & Date 2 & $\begin{array}{l}\text { Separation } \\
\text { (Days) }\end{array}$ \\
\hline 1 & $\begin{array}{l}\text { Homeless Anja Joos is beaten up to } \\
\text { death by personnel of a local super- } \\
\text { market in Amsterdam }\end{array}$ & 6-Oct-03 & $\begin{array}{l}\text { Arnold Schwarzenegger is elected } \\
\text { governor of California }\end{array}$ & 7-Oct-03 & 1 \\
\hline 2 & $\begin{array}{l}\text { Socialite Paris Hilton is released after } \\
23 \text { days in prison }\end{array}$ & 26-Jun-07 & Tony Blair resigns as Prime Minister & 27-Jun-07 & 1 \\
\hline 3 & $\begin{array}{l}\text { American girl Natalee Holloway dis- } \\
\text { appears on Aruba }\end{array}$ & 30-May-05 & $\begin{array}{l}\text { Dutch voters reject the European con- } \\
\text { stitution in a referendum }\end{array}$ & 1-Jun-05 & 2 \\
\hline 4 & $\begin{array}{l}\text { A student shoots his teacher at the } \\
\text { Terra College in The Hague }\end{array}$ & 10-Jan-04 & $\begin{array}{l}\text { City councilman Rob Oudkerk causes } \\
\text { a stir after he uses his work computer } \\
\text { to visit porn sites }\end{array}$ & 13-Jan-04 & 3 \\
\hline $5^{*}$ & $\begin{array}{l}\text { On Bali, } 202 \text { people are killed in } \\
\text { bomb attacks }\end{array}$ & 12-Oct-02 & $\begin{array}{l}\text { The first administration of Prime } \\
\text { Minister Balkenende, which includes } \\
\text { LPF, resigns }\end{array}$ & $16-$ Oct-02 & 4 \\
\hline $6^{*}$ & $\begin{array}{l}\text { Hans Blix inspects Iraq for weapons } \\
\text { of mass destruction }\end{array}$ & 18-Nov-02 & $\begin{array}{l}\text { Author Boudewijn Büch dies of an } \\
\text { heart attack }\end{array}$ & 23-Nov-02 & 5 \\
\hline 7 & Princess Amalia is born & 7-Dec-03 & Saddam Hussein is arrested & 13-Dec-03 & 6 \\
\hline $8^{*}$ & Opera singer Luciano Pavarotti dies & 6-Sep-07 & Politician Rita Verdonk is expelled & 13-Sep-07 & 7 \\
\hline
\end{tabular}
from the parliamentary faction of the VVD 
APPENDIX A (Continued)

\begin{tabular}{|c|c|c|c|c|c|}
\hline Pair & Event 1 & Date 1 & Event 2 & Date 2 & $\begin{array}{l}\text { Separation } \\
\text { (Days) }\end{array}$ \\
\hline 9 & $\begin{array}{l}\text { The second administration of Prime } \\
\text { Minister Balkenende, which includes } \\
\text { D66, resigns }\end{array}$ & 29-Jun-06 & $\begin{array}{l}\text { Football player Zinedine Zidane } \\
\text { receives a red card at the final of the } \\
\text { World Cup }\end{array}$ & 9-Jul-06 & 10 \\
\hline 10 & $\begin{array}{l}\text { Swedish minister of Foreign Affairs, } \\
\text { Anna Lindh, is stabbed to death }\end{array}$ & 10-Sep-03 & $\begin{array}{l}\text { Johan Stekelenburg, the popular } \\
\text { mayor of Tilburg, dies }\end{array}$ & 23-Sep-03 & 13 \\
\hline 11 & $\begin{array}{l}\text { Popular singer Frans Bauer cancels } \\
\text { his concerts, because he has a polyp } \\
\text { on his vocal cords }\end{array}$ & 27-Nov-06 & $\begin{array}{l}\text { Singer Robert Long dies at the age } \\
\text { of } 63\end{array}$ & 13-Dec-06 & 16 \\
\hline $12^{*}$ & $\begin{array}{l}\text { Space Shuttle Columbia explodes } \\
\text { shortly after lift-off }\end{array}$ & 1-Feb-03 & SARS breaks out in Hong Kong & 22-Feb-03 & 21 \\
\hline 13 & Prince Bernhard dies & 1-Dec-04 & Tsunami in Southeast Asia & 26-Dec-04 & 25 \\
\hline 14 & $\begin{array}{l}\text { The widow of fascist leader Rost-Van } \\
\text { Tonningen dies }\end{array}$ & 24-Mar-07 & $\begin{array}{l}\text { Four-year-old Madeleine McCann } \\
\text { disappears in Portugal }\end{array}$ & 3-Мay-07 & 40 \\
\hline 15 & Singer André Hazes dies & 23-Sep-04 & $\begin{array}{l}\text { Filmmaker Theo van Gogh is assas- } \\
\text { sinated in Amsterdam }\end{array}$ & 2-Nov-04 & 40 \\
\hline 16 & $\begin{array}{l}\text { Fifty-two people die during the bomb } \\
\text { attacks on the London subway }\end{array}$ & 7-Jul-05 & $\begin{array}{l}\text { Hurricane Katrina causes floods in } \\
\text { New Orleans }\end{array}$ & 29-Aug-05 & 53 \\
\hline $17^{*}$ & Pope Benedict XVI is elected & 19-Apr-05 & $\begin{array}{l}\text { Michael Jackson is acquitted of child } \\
\text { abuse }\end{array}$ & 16-Jun-05 & 58 \\
\hline 18 & Yasser Arafat dies in Paris & 11-Nov-04 & $\begin{array}{l}\text { In Amsterdam a woman runs over the } \\
\text { thief who had just stolen her purse } \\
\text { with her car }\end{array}$ & 17-Jan-05 & 67 \\
\hline 19 & Freddie Heineken dies at the age of 78 & 3-Jan-02 & $\begin{array}{l}\text { Politician Pim Fortuyn is assassinated } \\
\text { in Hilversum }\end{array}$ & 6-May-02 & 123 \\
\hline 20 & $\begin{array}{l}\text { A hoax television show in which } \\
\text { participants can win a kidney donor } \\
\text { causes a big stir }\end{array}$ & 6-Jan-07 & $\begin{array}{l}\text { Gorilla Bokito escapes in the Zoo of } \\
\text { Rotterdam }\end{array}$ & 18-May-07 & 132 \\
\hline 21 & Queen Mother Juliana dies & 20-Mar-04 & $\begin{array}{l}\text { During a hostage crisis in a school in } \\
\text { Beslan, } 344 \text { people die }\end{array}$ & 1-Sep-04 & 165 \\
\hline $22^{*}$ & $\begin{array}{l}\text { Musician and painter Herman Brood } \\
\text { commits suicide }\end{array}$ & 11-Jul-01 & $\begin{array}{l}\text { Prince Willem-Alexander and Prin- } \\
\text { cess Maxima marry in Amsterdam }\end{array}$ & 2-Feb-02 & 206 \\
\hline 23 & $\begin{array}{l}\text { Steve 'Crocodile Hunter' Irwin dies } \\
\text { after his chest was pierced by a sting- } \\
\text { ray barb }\end{array}$ & 4-Sep-06 & $\begin{array}{l}\text { A South-Korean student shoots } 32 \\
\text { people at a university in the United } \\
\text { States }\end{array}$ & 16-Apr-07 & 224 \\
\hline 24 & $\begin{array}{l}\text { Danish embassies around the world } \\
\text { are attacked because of cartoons of } \\
\text { the prophet Muhammad }\end{array}$ & 4-Feb-06 & $\begin{array}{l}\text { Popular music group BZN quit after } \\
41 \text { years }\end{array}$ & 16-Jun-07 & 496 \\
\hline 25 & $\begin{array}{l}\text { Deputy Minister Philomena Bijlhout } \\
\text { resigns after only one day in office }\end{array}$ & 22-Jul-02 & $\begin{array}{l}\text { Actress Guusje Nederhorst dies of } \\
\text { cancer at the age of } 34\end{array}$ & 29-Jan-04 & 556 \\
\hline 26 & $\begin{array}{l}\text { Hostage Arjan Erkel who works for } \\
\text { Médecins Sans Frontières is released } \\
\text { from captivity in Dagestan }\end{array}$ & 10-Apr-04 & $\begin{array}{l}\text { Eleven people die in a fire in a deten- } \\
\text { tion center near Schiphol Airport }\end{array}$ & 27-Oct-05 & 565 \\
\hline 27 & $\begin{array}{l}\text { Cabinet Balkenende I, which includes } \\
\text { LPF, is inaugurated }\end{array}$ & 22-Jul-02 & Deputy Minister Bijlhout resigns & 23-Jul-02 & 1 \\
\hline 28 & $\begin{array}{l}\text { French voters reject the European } \\
\text { constitution in a referendum }\end{array}$ & 29-May-05 & $\begin{array}{l}\text { Dutch voters also reject the European } \\
\text { constitution }\end{array}$ & 1-Jun-05 & 3 \\
\hline 29 & $\begin{array}{l}\text { Journalists Joost de Haas and Bart } \\
\text { Mos are incarcerated }\end{array}$ & 27-Nov-06 & $\begin{array}{l}\text { De Haas and Mos are released from } \\
\text { prison }\end{array}$ & 30-Nov-06 & 3 \\
\hline 30 & $\begin{array}{l}\text { Lawyer Moszkowicz loses libel case } \\
\text { against Jort Kelder, who had called } \\
\text { him 'mob buddy' }\end{array}$ & $15-\mathrm{Feb}-07$ & $\begin{array}{l}\text { Moszkowicz give the defense of Hol- } \\
\text { leeder over to Kuijpers }\end{array}$ & 19-Feb-07 & 4 \\
\hline 31 & $\begin{array}{l}\text { The Dutch national soccer team loses } \\
\text { to Portugal during the European } \\
\text { Championships in } 2004\end{array}$ & 30-Jun-04 & Coach Advocaat resigns & 6-Jul-04 & 6 \\
\hline 32 & Pim Fortuyn is assassinated & 6-Мay-02 & LPF wins 26 seats in parliament & 15-May-02 & 9 \\
\hline
\end{tabular}


APPENDIXA (Continued)

\begin{tabular}{|c|c|c|c|c|c|}
\hline Pair & Event 1 & Date 1 & Event 2 & Date 2 & $\begin{array}{l}\text { Separation } \\
\text { (Days) }\end{array}$ \\
\hline 33 & $\begin{array}{l}\text { Fifteen British marines are arrested in } \\
\text { Iranian waters }\end{array}$ & 23-Mar-07 & $\begin{array}{l}\text { The British marines are released by } \\
\text { Iran }\end{array}$ & 4-Apr-07 & 12 \\
\hline 34 & Pope John Paul II dies & 2-Apr-05 & Pope Benedict XVI is elected & 19-Apr-05 & 17 \\
\hline 35 & $\begin{array}{l}\text { Socialite Paris Hilton goes to prison } \\
\text { because she drove without a license }\end{array}$ & 5-Jun-07 & Paris Hilton is released from prison & 26-Jun-07 & 21 \\
\hline 36 & $\begin{array}{l}\text { An armed conflict between Israel and } \\
\text { Hezbollah in Lebanon starts, after } \\
\text { two Israeli soldiers were kidnapped }\end{array}$ & 13-Jul-06 & $\begin{array}{l}\text { A ceasefire between Israel and Hez- } \\
\text { bollah is declared }\end{array}$ & 14-Aug-06 & 32 \\
\hline 37 & $\begin{array}{l}\text { The U.S. and U.K. invade Iraq, be- } \\
\text { cause they suspect Hussein of making } \\
\text { weapons of mass destruction }\end{array}$ & 20-Mar-03 & $\begin{array}{l}\text { President Bush declares on an aircraft } \\
\text { carrier that the mission in Iraq is } \\
\text { 'accomplished' }\end{array}$ & 1-May-03 & 42 \\
\hline 38 & $\begin{array}{l}\text { Author Jan Wolkers dies on the island } \\
\text { of Texel }\end{array}$ & 19-Oct-07 & $\begin{array}{l}\text { Wolkers' text is used during the } \\
\text { Grand Dictee of the Dutch Language }\end{array}$ & 19-Dec-07 & 61 \\
\hline 39 & $\begin{array}{l}\text { Cabinet Balkenende I, which includes } \\
\text { LPF, is inaugurated }\end{array}$ & 22-Jul-02 & $\begin{array}{l}\text { Cabinet Balkenende I falls, after LPF } \\
\text { Ministers Bomhoff and Heinsbroek } \\
\text { resign }\end{array}$ & $16-O c t-02$ & 86 \\
\hline 40 & $\begin{array}{l}\text { 'An Inconvenient Truth' that was pre- } \\
\text { sented by Al Gore wins the Academy } \\
\text { Award for best documentary }\end{array}$ & $25-\mathrm{Feb}-07$ & $\begin{array}{l}\text { It is announced that Al Gore has won } \\
\text { the Nobel Peace Prize }\end{array}$ & 12-Oct-07 & 229 \\
\hline 41 & Queen Mother Juliana dies & 20-Mar-04 & Prince Bernhard dies & 1-Dec-04 & 266 \\
\hline 42 & $\begin{array}{l}\text { Rita Verdonk receives more votes } \\
\text { than her party leader }\end{array}$ & 22-Nov-06 & $\begin{array}{l}\text { Rita Verdonk is removed from the } \\
\text { Liberal party }\end{array}$ & 14-Sep-07 & 296 \\
\hline 43 & $\begin{array}{l}\text { Eleven people die in a fire in a deten- } \\
\text { tion center near Schiphol Airport }\end{array}$ & 27-Oct-05 & $\begin{array}{l}\text { Ministers Donner and Dekker have to } \\
\text { resign, because of a fire in a deten- } \\
\text { tion center near Schiphol Airport }\end{array}$ & 21-Sep-06 & 329 \\
\hline 44 & $\begin{array}{l}\text { In four trains in Madrid bombs go } \\
\text { off, killing } 192 \text { people }\end{array}$ & 11-Mar-04 & $\begin{array}{l}\text { Several bombs go off in the London } \\
\text { subway, killing } 56 \text { people }\end{array}$ & 7-Jul-05 & 483 \\
\hline 45 & Willem Endstra is shot dead & 17-May-04 & $\begin{array}{l}\text { Willem Holleeder is arrested for } \\
\text { blackmailing Endstra }\end{array}$ & 29-Jan-06 & 622 \\
\hline 46 & Pim Fortuyn is assassinated & 6-May-02 & $\begin{array}{l}\text { Filmmaker Theo van Gogh is stabbed } \\
\text { to death in Amsterdam }\end{array}$ & 2-Nov-04 & 911 \\
\hline
\end{tabular}

APPENDIX B

\begin{tabular}{|c|c|c|c|c|c|}
\hline Pair & Event 1 & Date 1 & Event 2 & Date 2 & $\begin{array}{l}\text { Separation } \\
\text { (Days) }\end{array}$ \\
\hline 1 & $\begin{array}{l}\text { French voters reject the European } \\
\text { constitution in a referendum }\end{array}$ & 29-May-05 & $\begin{array}{l}\text { Dutch voters reject the European } \\
\text { constitution }\end{array}$ & 1-Jun-05 & 3 \\
\hline 2 & $\begin{array}{l}\text { Journalists Joost de Haas and Bart } \\
\text { Mos are incarcerated }\end{array}$ & 27-Nov-06 & $\begin{array}{l}\text { Journalists De Haas and Mos are re- } \\
\text { leased from prison }\end{array}$ & 30-Nov-06 & 3 \\
\hline 3 & $\begin{array}{l}\text { Lawyer Moszkowicz loses libel case } \\
\text { against Jort Kelder, who had called } \\
\text { him 'mob buddy' }\end{array}$ & $15-F e b-07$ & $\begin{array}{l}\text { Moszkowicz gives the defense of } \\
\text { Holleeder over to Kuijpers }\end{array}$ & 19-Feb-07 & 4 \\
\hline 4 & $\begin{array}{l}\text { Hundreds of people are killed in } \\
\text { South Ossetia during fights between } \\
\text { the Georgian and Russian army }\end{array}$ & 7-Aug-08 & $\begin{array}{l}\text { Stan Storimans, who works for RTL } \\
\text { Nieuws, dies in Georgia }\end{array}$ & 12-Aug-08 & 5 \\
\hline 5 & $\begin{array}{l}\text { The Dutch national soccer team loses } \\
\text { to Portugal during the European } \\
\text { Championships in } 2004\end{array}$ & 30-Jun-04 & Coach Advocaat resigns & 6-Jul-04 & 6 \\
\hline 6 & Pope John Paul II dies & 2-Apr-05 & Pope Benedict XVI is elected & 19-Apr-05 & 17 \\
\hline 7 & $\begin{array}{l}\text { The Dutch, Belgian and Luxemburg } \\
\text { governments take a } 49 \% \text { stake in } \\
\text { Fortis }\end{array}$ & 28-Sep-08 & $\begin{array}{l}\text { ING receives } 10 \text { billion euro from the } \\
\text { Dutch government }\end{array}$ & $17-O c t-08$ & 19 \\
\hline
\end{tabular}


APPENDIX B (Continued)

\begin{tabular}{|c|c|c|c|c|c|}
\hline Pair & Event 1 & Date 1 & Event 2 & Date 2 & $\begin{array}{l}\text { Separation } \\
\text { (Days) }\end{array}$ \\
\hline 8 & $\begin{array}{l}\text { Socialite Paris Hilton goes to prison, } \\
\text { because she drove without a license }\end{array}$ & 5-Jun-07 & Paris Hilton is released from prison & 26-Jun-07 & 21 \\
\hline 9 & $\begin{array}{l}\text { The armed conflict between Israel and } \\
\text { Hezbollah in Lebanon starts, after two } \\
\text { Israeli soldiers were kidnapped }\end{array}$ & 13-Jul-06 & $\begin{array}{l}\text { A ceasefire between Israel and Hez- } \\
\text { bollah is declared }\end{array}$ & 14-Aug-06 & 32 \\
\hline 10 & $\begin{array}{l}\text { Author and artist Jan Wolkers dies on } \\
\text { the island of Texel }\end{array}$ & 19-Oct-07 & $\begin{array}{l}\text { Wolkers' text is used during the Grand } \\
\text { Dictee of the Dutch Language }\end{array}$ & 19-Dec-07 & 61 \\
\hline 11 & $\begin{array}{l}\text { The film 'Submission' by Theo van } \\
\text { Gogh and Ayaan Hirsi Ali is shown } \\
\text { on television }\end{array}$ & 29-Aug-04 & $\begin{array}{l}\text { Filmmaker Theo van Gogh is stabbed } \\
\text { to death in Amsterdam }\end{array}$ & 2-Nov-04 & 65 \\
\hline 12 & $\begin{array}{l}\text { The Treaty of Lisbon is signed by the } \\
\text { leaders of the members of the Euro- } \\
\text { pean Union }\end{array}$ & 13-Dec-07 & $\begin{array}{l}\text { Ireland rejects the Treaty of Lisbon in } \\
\text { a referendum }\end{array}$ & 12-Jun-08 & 182 \\
\hline 13 & Queen Mother Juliana dies & 20-Mar-04 & Prince Bernhard dies & 1-Dec-04 & 266 \\
\hline 14 & $\begin{array}{l}\text { The diary of Tanja Nijmeijer, who } \\
\text { had become a member of FARC, is } \\
\text { found }\end{array}$ & 3-Sep-07 & $\begin{array}{l}\text { Colombian presidential candidate } \\
\text { Ingrid Betancourt is liberated after } \\
\text { six years }\end{array}$ & 2-Jul-08 & 303 \\
\hline 15 & $\begin{array}{l}\text { Rita Verdonk receives more votes } \\
\text { than her party leader }\end{array}$ & 22-Nov-06 & $\begin{array}{l}\text { Rita Verdonk founds her own politi- } \\
\text { cal party }\end{array}$ & 17-Oct-07 & 329 \\
\hline 16 & Willem Endstra is shot dead & 17-May-04 & $\begin{array}{l}\text { Willem Holleeder is arrested for } \\
\text { blackmailing Endstra }\end{array}$ & 29-Jan-06 & 622 \\
\hline 17 & $\begin{array}{l}\text { Several bombs go off in the London } \\
\text { subway, killing } 56 \text { people }\end{array}$ & 7-Jul-05 & Tony Blair resigns as Prime Minister & 27-Jun-07 & 720 \\
\hline 18 & $\begin{array}{l}\text { American girl Natalee Holloway dis- } \\
\text { appears on Aruba }\end{array}$ & 30-May-05 & $\begin{array}{l}\text { Joran van der Sloot admits in a } \\
\text { broadcast that he was involved in the } \\
\text { disappearance of Natalee Holloway }\end{array}$ & 3-Feb-08 & 979 \\
\hline 19 & Paris Hilton is released from prison & 26-Jun-07 & Tony Blair resigns as Prime Minister & 27-Jun-07 & 1 \\
\hline 20 & $\begin{array}{l}\text { Rita Verdonk founds her own politi- } \\
\text { cal party }\end{array}$ & $17-$ Oct-07 & $\begin{array}{l}\text { Author and artist Jan Wolkers dies on } \\
\text { the island of Texel }\end{array}$ & 19-Oct-07 & 2 \\
\hline 21 & $\begin{array}{l}\text { American girl Natalee Holloway dis- } \\
\text { appears on Aruba }\end{array}$ & 30-May-05 & $\begin{array}{l}\text { Dutch voters reject the European } \\
\text { constitution }\end{array}$ & 1-Jun-05 & 2 \\
\hline 22 & $\begin{array}{l}\text { Rita Verdonk receives more votes } \\
\text { than her party leader }\end{array}$ & 22-Nov-06 & $\begin{array}{l}\text { Journalists Joost de Haas and Bart } \\
\text { Mos are incarcerated }\end{array}$ & 27-Nov-06 & 5 \\
\hline 23 & $\begin{array}{l}\text { The Treaty of Lisbon is signed by the } \\
\text { leaders of the members of the Euro- } \\
\text { pean Union }\end{array}$ & 13-Dec-07 & $\begin{array}{l}\text { Wolkers' text is used during the } \\
\text { Grand Dictee of the Dutch Language }\end{array}$ & 19-Dec-07 & 6 \\
\hline 24 & $\begin{array}{l}\text { Ireland rejects the Treaty of Lisbon in } \\
\text { a referendum }\end{array}$ & 12-Jun-08 & $\begin{array}{l}\text { Colombian presidential candidate } \\
\text { Ingrid Betancourt is liberated after } \\
\text { six years }\end{array}$ & 2-Jul-08 & 19 \\
\hline 25 & $\begin{array}{l}\text { Stan Storimans, who works for RTL } \\
\text { Nieuws, dies in Georgia }\end{array}$ & 12-Aug-08 & $\begin{array}{l}\text { The diary of Tanja Nijmeijer, who } \\
\text { had become a member of FARC, is } \\
\text { found }\end{array}$ & 3-Sep-07 & 22 \\
\hline 26 & $\begin{array}{l}\text { Filmmaker Theo van Gogh is stabbed } \\
\text { to death in Amsterdam }\end{array}$ & 2-Nov-04 & Prince Bernhard dies & 1-Dec-04 & 29 \\
\hline 27 & Willem Endstra is shot dead & 17-May-04 & Coach Advocaat resigns & 6-Jul-04 & 50 \\
\hline 28 & Pope John Paul II dies & 2-Apr-05 & $\begin{array}{l}\text { French voters reject the European } \\
\text { constitution in a referendum }\end{array}$ & 29-May-05 & 57 \\
\hline 29 & $\begin{array}{l}\text { Journalists De Haas and Mos are re- } \\
\text { leased from prison }\end{array}$ & 30-Nov-06 & $\begin{array}{l}\text { Lawyer Moszkowicz loses libel case } \\
\text { against Jort Kelder, who had called } \\
\text { him 'mob buddy' }\end{array}$ & $15-F e b-07$ & 77 \\
\hline 30 & Queen Mother Juliana dies & 20-Mar-04 & $\begin{array}{l}\text { The Dutch national soccer team loses } \\
\text { to Portugal during the European } \\
\text { Championships in } 2004\end{array}$ & 30-Jun-04 & 102 \\
\hline 31 & $\begin{array}{l}\text { Joran van der Sloot admits in a } \\
\text { broadcast that he was involved in the } \\
\text { disappearance of Natalee Holloway }\end{array}$ & 3-Feb-08 & $\begin{array}{l}\text { Hundreds of people are killed in } \\
\text { South Ossetia during fights between } \\
\text { the Georgian and Russian army }\end{array}$ & 7-Aug-08 & 186 \\
\hline
\end{tabular}


APPENDIX B (Continued)

\begin{tabular}{|c|c|c|c|c|c|}
\hline Pair & Event 1 & Date 1 & Event 2 & Date 2 & $\begin{array}{l}\text { Separation } \\
\text { (Days) }\end{array}$ \\
\hline 32 & $\begin{array}{l}\text { A ceasefire between Israel and Hez- } \\
\text { bollah is declared }\end{array}$ & 14-Aug-06 & $\begin{array}{l}\text { Moszkowicz gives the defense of } \\
\text { Holleeder over to Kuijpers }\end{array}$ & 19-Feb-07 & 189 \\
\hline 33 & $\begin{array}{l}\text { The film 'Submission' by Theo van } \\
\text { Gogh and Ayaan Hirsi Ali is shown } \\
\text { on television }\end{array}$ & 29-Aug-04 & Pope Benedict XVI is elected & 19-Apr-05 & 233 \\
\hline 34 & $\begin{array}{l}\text { Several bombs go off in the London } \\
\text { subway, killing } 56 \text { people }\end{array}$ & 7-Jul-05 & $\begin{array}{l}\text { Socialite Paris Hilton goes to prison, } \\
\text { because she drove without a license }\end{array}$ & 5-Jun-07 & 698 \\
\hline 35 & $\begin{array}{l}\text { The armed conflict between Is- } \\
\text { rael and Hezbollah in Lebanon } \\
\text { starts, after two Israeli soldiers are } \\
\text { kidnapped }\end{array}$ & 13-Jul-06 & $\begin{array}{l}\text { ING receives } 10 \text { billion euro from the } \\
\text { Dutch government }\end{array}$ & $17-$-Oct- 08 & 827 \\
\hline 36 & $\begin{array}{l}\text { Willem Holleeder is arrested for } \\
\text { blackmailing Endstra }\end{array}$ & 29-Jan-06 & $\begin{array}{l}\text { The Dutch, Belgian and Luxemburg } \\
\text { governments take a } 49 \% \text { stake in } \\
\text { Fortis }\end{array}$ & 28-Sep-08 & 972 \\
\hline
\end{tabular}

(Manuscript received November 10, 2009; revision accepted for publication May 17, 2010.) 